\title{
On the Occurrence of a Haemogregarinae (Apicomplexa) Parasite from Freshwater Turtles of South 24 Parganas, West Bengal, India
}

\author{
Hindistan (Batı Bengal)'daki Tatlısu Kaplumbağalarında Hemogregarin (Apicomplexa)
}

\section{Parazitin Bulunuşu}

\author{
Sabir Hossen Molla', Probir K. Bandyopadhyay', Gözde Gürelli² \\ 'Department of Zoology, Parasitology Laboratory, University of Kalyani, Kalyani-West Bengal, India \\ 2Department of Biology, Kastamonu University, Faculty of Arts and Sciences, Kastamonu, Turkey
}

\section{ABSTRACT}

Objective: The aim of this study was to investigate Haemogregarine parasites (Apicomplexa: Haemogregarinidae) of freshwater turtles (Lissemys punctata andersoni, Geoclemys hamiltonii) of India.

Methods: Turtles were collected by net from two ponds of South 24 Parganas, West Bengal, India. A small amount of blood was taken from the subcarapacial vein puncture site. The blood smears were prepared and air dried and fixed in absolute methyl alcohol. The slides were stained with Giemsa.

Results: Haemogregarine parasites were recorded from the erythrocytes of turtles. Multiple stages of intraerythrocytic gametocytes (microgametocytes, macrogametocytes, early schizonts and mature schizonts) were observed in blood films.

Conclusion: It was found that only twenty out of the twenty five turtles (80\%) were infected with the parasite. The prevalence rate was higher in larger turtles in comparison to smaller ones. It was also found that female turtles had a higher prevalence of infection than males. (Turkiye Parazitol Derg 2013; 37: 118-22)

Key Words: Haemogregarine parasite, freshwater, turtle, Lissemys punctata andersoni, Geoclemys hamiltonii, India

Received: 07.01.2013

Accepted: 05.03.2013

\section{ÖZET}

Amaç: Bu çalışmanın amacı Hindistan'daki tatlısu kaplumbağalarını (Lissemys punctata andersoni, Geoclemys hamiltonii) Hemogregarin parazitler (Apicomplexa: Haemogregarinidae) açısından araştırmaktır.

Yöntemler: Kaplumbağalar Hindistan'ın Batı Bengal bölgesindeki iki tatlısu kaynağından ağ ile toplanmıştır. Karapaks altındandaki toplardamardan az miktarda kan alınmıştır. Kan yayma preparatları hava yardımıyla kurutulmuş ve absolü metal alkolde tespit edilmiştir. Preparatlar Giemsa'yla boyanmıştır.

Bulgular: Kaplumbağaların eritrositlerinde Hemogregarin parazit saptanmıştır. Kan yayma preparatlarında eritrosit içi gametositlerin çeşitli safhaları (mikrogametositler, makrogametositler, genç şizontlar ve olgun şizontlar) gözlemlenmiştir.

Sonuç: Incelenen 25 kaplumbağanın 20'si (\%80) parazitle enfektedir. Parazitin yaygınlık oranı büyük kaplumbağalarda küçüklere oranla daha fazladır. Dişi kaplumbağaların erkek kaplumbağalardan daha yüksek enfeksiyon yaygınlığına sahip olduğu da tespit edilmiştir. (Turkiye Parazitol Derg 2013; 37: 118-22)

Anahtar Sözcükler: Hemogregarin parazit, tatlısu, kaplumbağa, Lissemys punctata andersoni, Geoclemys hamiltonii, Hindistan Geliş Tarihi: 07.01.2013

Kabul Tarihi: 05.03.2013

Address for Correspondence / Yazışma Adresi: Dr. Gözde Gürelli, Department of Biology, Kastamonu University, Faculty of Arts and Sciences, Kastamonu, Turkey Phone: +90 5446778927 E-mail: ggurelli@yahoo.com doi:10.5152/tpd.2013.27 


\section{INTRODUCTION}

Turtles are primitive animals and parasites of turtles bear a great importance from an evolutionary point of view. Freshwater turtles are generally prone to various intraerythrocytic blood parasites infection (1-3). In 2009, Telford established that intracellular erythrocytes are common and widely distributed in freshwater turtle (4). These parasites are found in the cytoplasm of host erythrocytes, are banana shaped and are not necessarily hostspecific (5).

Haemogregarines were first described by Danilewsky in 1885 from a European tortoise, Emys orbicularis (Linn) (6). The detailed account of the structure and life cycle of Haemogregarine parasite in the same tortoise was described by Reichnow in 1910 (7). In India, chelonian Haemogregarine was first observed by Simond in 1901 who described two Haemogregarines, Haemogregarina laverani and Haemogregarina mesnili (8); they worked on Emyda granosa and Emys tectum, respectively. Many scientists like Wang and Hopkings (9), Marquard (10), Strohlein and Christensen (11), McAuliffe (12), Acholonu (13), Edney (14) and Siddal and Desser (15), have worked a lot on Haemogregarine infection of turtles. The parasite takes up over half of the volume of an infected erythrocyte and destroys the host's blood cell causing anaemia $(16,17)$. According to Sheldon and Verhulst (18), the host develops an immune defence against the parasite. Haemogregarines have an indirect life cycle involving definitive invertebrate hosts and vertebrate hosts such as lizards, turtle, snake or frogs (19-21).

Wintrobe (22) established that Haemogregarines cause a depletion of haematocrit levels. As a result, infected turtles may have reduced concentrations of haemoglobin and the capacity for oxygen transportation to muscle tissue $(23,24)$. The parasites are mechanically transmitted by either mite or tick or by arthropod or leech. According to Paperna (25) and Siddal and Desser (26) the Haemogregarine infections are thought to be transmitted by leeches as the vector. Readel et al. (27) reported that because of the large surface area, the hosts are more prone to leech attachment.

Kntotkova et al. (28) established that heavy infection with Haemogregarines causes poor health in turtle populations. Paperna (25) and Siddal and Desser (26) reported that bottomdwelling turtles are more prone to infection than basking turtles. Ryan and Lambert (29) and Strohlein and Christensen (30) also observed the highest infection of Haemogregarines in bottomdwelling turtle. Moreover, McCoy et al. (31) reported that female hosts are more susceptible to infection than males.

The aim of this study was to investigate Haemogregarine parasites (Apicomplexa: Haemogregarinidae) of freshwater turtles (Lissemys punctata andersoni, Geoclemys hamiltonii) in (West Bengal) India.

\section{METHODS}

Turtles were captured from two ponds located in the South 24 Parganas district of West Bengal, India, using nets. Two species were collected from the pond for examination and brought to the laboratory alive. The length of carapace $(C L)$ of each indi- vidual was recorded. A small amount of blood was taken from subcarapacial vein puncture site. The blood smears were prepared and then air dried and fixed in absolute methyl alcohol. Then, the slides were stained with Giemsa (pH 6-8) for 45 minutes and dried again. The dried slides were mounted in DPX. Finally, all the turtles were left on the sand to recover for about 2-3 hours before being transferred back to the water.

\section{RESULTS}

The slides were examined under the phase contrast microscope for identification of the parasite. The Haemogregarine parasites stained light blue with Giemsa. Due to the presence of parasites, the shape of the erythrocytes was changed; the red blood cells became elongated in order to accommodate the parasite, and the nucleus of the erythrocyte became displaced to one pole. The cells looks like banana-shaped. Multiple stages of intraerythrocytic Haemogregarine gametocytes were observed in blood films including microgametocytes, macrogametocytes, early schizonts and mature schizonts. The microgametocytes were kidney-bean shaped with a light cytoplasm and disperse nucleus. (Fig. 1A, B). The average area of microgametocytes was found to be $20.896 \pm 0.42 \mu \mathrm{m}^{2}$. The macrogametocytes were elongated, slightly curved with granulated deep stain cytoplasm and condensed nucleus (Fig. 1C, D). The average area of macrogametocytes was found to be $24.907 \pm 0.64 \mu \mathrm{m}^{2}$. Intraerythrocytic early schizonts were oval- to bean-shaped with four nuclei (Fig. $1 \mathrm{E}, \mathrm{F})$, and an average area of $35.078 \pm 0.63 \mu \mathrm{m}^{2}$. The mature schizonts were bean-shaped and contained eight nuclei (Figure $1 G, H)$. The average area of mature schizonts was found to be 29.168 $\pm 0.31 \mu \mathrm{m}^{2}$ (Table 1).

A total of twenty five turtles were collected and examined for Haemogregarine parasites. The Lissemys punctata andersoni and Geoclemys hamiltonii were infected with a prevalence rate of $93.33 \%$ and $60.0 \%$, respectively (Table 2 ). There were significant differences in relation to body size of the host. The prevalence rate was higher in larger turtles in comparison to smaller ones (Table 3). It was found that only twelve out of thirteen (92.31\%) females and eight out of twelve (66.66\%) males were infected with Haemogregarine parasites (Table 4). Therefore, it appeared that female turtles were more susceptible to infection.

\section{DISCUSSSION}

The different developmental stages found in this study agree with the findings of Paperna et al. (32). The morphological characteristics of gametocytes have been rejected by many authors $(33,34)$ as valid criteria for differentiating genera of Haemogregarines because: (i) the gametocytes of two or more species may be present in the same vertebrate host (35), (ii) confusion may arise between mature and immature gametocytes of the same species, which could also be considered different species (34), and (iii) macro- and microgametocytes of the same species might be considered different species $(35,36)$. Therefore, the developmental stages found in vertebrate hosts (intermediate host) and invertebrate hosts (definitive host) involved in the life-cycle, and the biogeography and ecology of the vertebrate hosts, have been used to differentiate genera of these blood parasites. On the basis of some characteristics of the develop- 


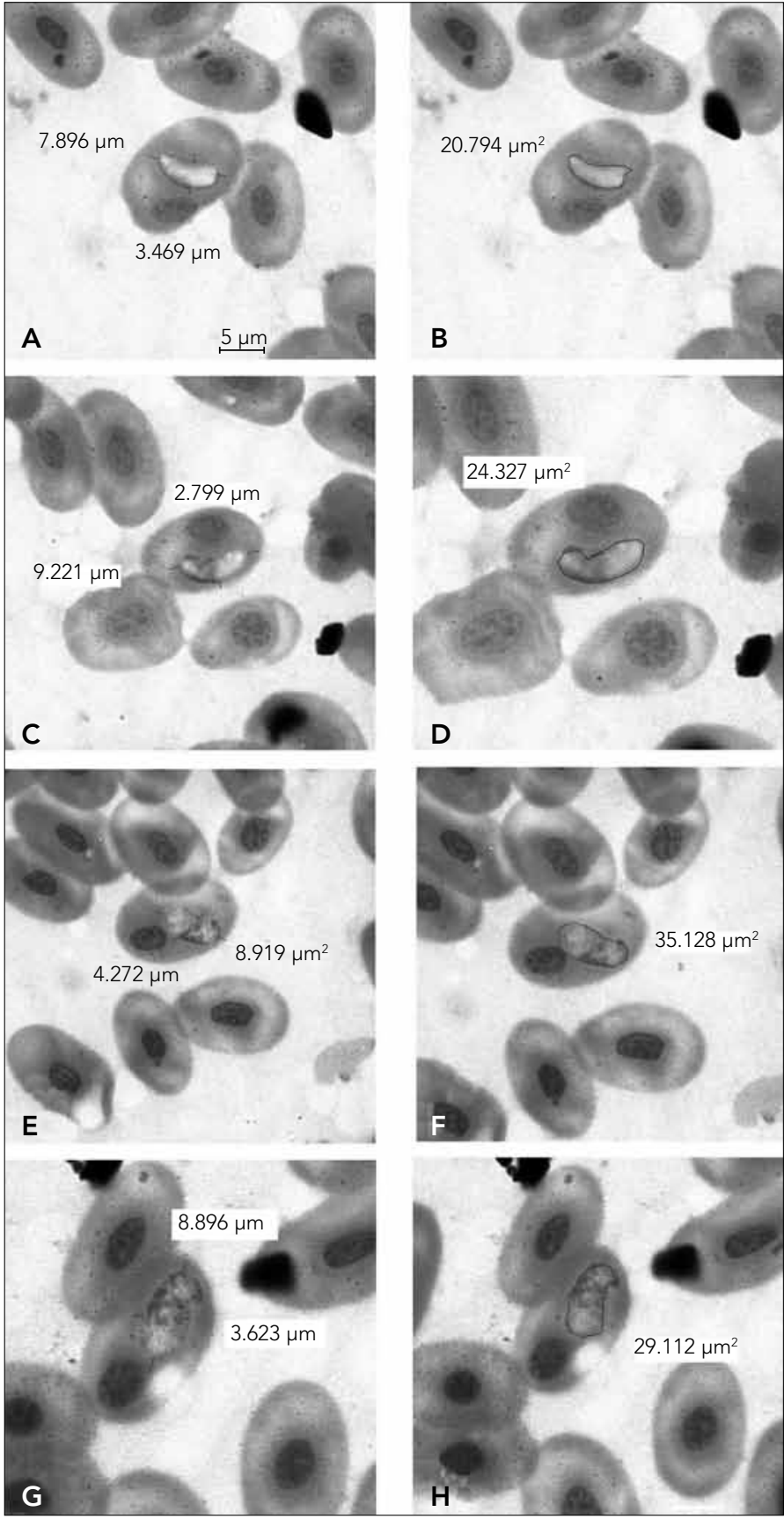

Figure 1. Multiple stages of intraerythrocytic Haemogregarine gametocytes. A, B. Microgametes, C, D. Macrogametes, E, F. Early schizonts, G, H. Mature schizonts

mental stages, it is confirmed that the organism belongs to the genera Haemogregarina.

The study revealed that the Haemogregarine infection was highest in turtles; infections were found in all two turtle species. In the present study, the overall prevalence of Haemogregarine in freshwater turtles was $80 \%$. Many differences in the prevalence of infection were found between different turtle species, sexes and size. Lissemys punctata andersoni and Geoclemys hamiltonii were infected with a prevalence of $93.33 \%$ and $60.0 \%$, respectively (Table 2 ). This agrees with the previous works $(25,26,29,30)$, which stated that bottom dwelling turtles,
Table 1. Measurement of different intraerythrocytic stages of haemogregarine parasite

\begin{tabular}{|l|c|c|c|}
\hline Diff. stages & $\begin{array}{c}\text { Length } \pm \text { SD } \\
\text { (range) } \\
\text { in } \boldsymbol{\mu m}\end{array}$ & $\begin{array}{c}\text { Width } \pm \text { SD } \\
\text { (range) } \\
\text { in } \boldsymbol{\mu m}\end{array}$ & $\begin{array}{c}\text { Area } \\
\text { (range) } \\
\text { in } \boldsymbol{\mu m}^{2}\end{array}$ \\
\hline Microgametocytes & $7.859 \pm 0.55$ & $3.657 \pm 0.28$ & $20.531 \pm 0.42$ \\
\hline Macrogametocytes & $9.152 \pm 0.48$ & $3.301 \pm 0.31$ & $24.907 \pm 0.64$ \\
\hline Early schizonts & $8.716 \pm 0.44$ & $4.170 \pm 0.22$ & $35.078 \pm 0.64$ \\
\hline Mature schizonts & $8.624 \pm 0.49$ & $3.607 \pm 0.32$ & $29.168 \pm 0.31$ \\
\hline SD: standard deviation & & \\
\end{tabular}

Table 2. Showing the prevalence of Haemogregarine infection in two freshwater turtles

\begin{tabular}{|c|c|c|c|c|}
\hline No. & $\begin{array}{c}\text { Name of } \\
\text { host species }\end{array}$ & $\begin{array}{c}\text { No. } \\
\text { examined }\end{array}$ & $\begin{array}{c}\text { No. } \\
\text { infection }\end{array}$ & $\begin{array}{c}\text { Prevalence } \\
\text { (\%) }\end{array}$ \\
\hline 01 & $\begin{array}{c}\text { Lissemys } \\
\text { punctata } \\
\text { andersoni }\end{array}$ & 15 & 14 & 93.33 \\
\hline 02 & $\begin{array}{c}\text { Geoclemys } \\
\text { hamiltonii }\end{array}$ & 10 & 06 & 60.00 \\
\hline
\end{tabular}

Table 3. Showing the levels of Haemogregarine parasitemia in turtle species examined in the study based on mean carapace length $(\mathrm{cm})$

\begin{tabular}{|c|c|c|c|c|}
\hline No. & $\begin{array}{c}\text { Name of } \\
\text { the } \\
\text { host species }\end{array}$ & $\begin{array}{c}\text { No. } \\
\text { infection }\end{array}$ & $\begin{array}{c}\text { Mean } \\
\text { carapace } \\
\text { length } \\
\text { (cm) }\end{array}$ & $\begin{array}{c}\text { Ave. } \\
\text { Parasitemia } \\
\text { (\% of } \\
\text { infected } \\
\text { erythrocytes) }\end{array}$ \\
\hline 01 & $\begin{array}{c}\text { Lissemys } \\
\text { punctata } \\
\text { andersoni }\end{array}$ & 14 & 29 & $0.91 \pm 0.12$ \\
\hline $\begin{array}{c}\text { Geoclemys } \\
\text { hamiltonii }\end{array}$ & 06 & 31 & $0.39 \pm 0.04$ \\
\hline
\end{tabular}

Table 4. Showing the prevalence of Haemogregarine infection in freshwater turtles based on sex

\begin{tabular}{|c|c|c|c|c|}
\hline No. & $\begin{array}{c}\text { Sex of the } \\
\text { host species }\end{array}$ & $\begin{array}{c}\text { No. } \\
\text { examined }\end{array}$ & $\begin{array}{c}\text { No. } \\
\text { infection }\end{array}$ & $\begin{array}{c}\text { Prevalence } \\
\text { (\%) }\end{array}$ \\
\hline 01 & Male & 12 & 08 & 66.66 \\
\hline 02 & Female & 13 & 12 & 92.31 \\
\hline
\end{tabular}

Lissemys punctata andersoni are more prone to the Haemogregarine infection than basking ones. There were significant differences in relation to the body size of the host; the prevalence rate was higher in larger turtles in comparison to smaller ones. Also, females were found to be more prone to infection than males, which are less affected. Since the surface area of females is large, the chance of infection is more. It can be said that all turtle species were susceptible to infection. The present study revealed that the prevalence of Haemogregarine infection was $80 \%$ in India, whereas it was $70 \%$ in North America (13), 93\% in Australia (37), and 100\% in Romania (38). 
Thus, it appeared that the infection rate was highest in Romania in comparison to other countries, which may be due to environmental pollution.

Multiple stages of intraerythrocytic Haemogregarine gametocytes were observed in blood films. Microgametocytes, macrogametocytes and early schizonts contain four nuclei whereas the mature schizonts have eight nuclei. The study revealed that the level of Haemogregarine infection was generally low in both turtles, varying from 0.39 to $0.91 \%$ of erythrocytes containing parasites, both of which are less than 1\% (Table 3). This work agrees with prior investigations made by Wang and Hopkins (9), McAuliffe (12), Storhlein and Christensen (11) and Siddal and Desser (15).

\section{CONCLUSION}

This observation corroborated with the findings of Oppliger et al. (23) and Veiga et al. (24). Due to the presence of Haemogregarine parasites, the turtles may have had reduced concentration of haemoglobin, meaning that the capacity for oxygen transportation to muscle tissue decreased. Since this is involved in various aspects of turtle physiology and behaviour, such as foraging efficiency or sprint speed, it may also affect the body condition. Therefore, it can be inferred that the Haemogregarine infection may cause damage to the blood cells which causes anaemia in the host.

\section{Conflict of Interest}

No conflict of interest was declared by the authors.

Peer-review: Externally peer-reviewed.

\section{Author Contributions}

Concept - P.K.B., S.H.M.; Design - P.K.B., S.H.M.; Supervision -P.K.B., S.H.M.; Funding - S.H.M.; Materials - P.K.B., S.H.M.; DataCollection and/or Processing - P.K.B., S.H.M.; Analysis and/ orlnterpretation - P.K.B., S.H.M.; Literature Review - P.K.B., S.H.M.;G.G.; Writing - P.K.B., S.H.M.; Critical Review - G.G.; Other - G.G., P.K.B., S.H.M.

\section{Acknowledgements}

One of the authors (S.H.M) is thankful to the head of the Department of Zoology, University of Kalyani, West Bengal for providing him research facilities and Dr R. Roy, associate professor (retd.) Barasat Govt. College, West Bengal for his suggestions during the research work.

\section{Çıkar Çatışması}

Yazarlar herhangi bir çıkar çatışması bildirmemişlerdir.

Hakem değerlendirmesi: Dış bağımsız.

\section{Yazar Katkıları}

Fikir - P.K.B., S.H.M.; Tasarım - P.K.B., S.H.M.; Denetleme - P.K.B., S.H.M.; Kaynaklar - S.H.M.; Malzemeler P.K.B., S.H.M.; Veri toplanması ve/veya işlemesi - P.K.B., S.H.M.; Analiz ve/veya yorum - P.K.B., S.H.M.; Literatur taraması - P.K.B., S.H.M.; G.G.; Yazıyı yazan - P.K.B., S.H.M.; Eleştirel Inceleme - G.G.; Diğer G.G., P.K.B., S.H.M.

\section{Teşekkür}

Sabir Hossen Molla, Kalyani Üniversitesi (West-Bengal) Zooloji Bölüm Başkanına ve Barasat Devlet Koleji (West Bengal)'nde Doçent olan Dr. R. Boy'a araştırması boyunca gösterdikleri kolaylıklardan ve önerilerden dolayı teşekkürlerini sunar.

\section{REFERENCES}

1. Segade P, Crespo C, Ayres C, Cordero A, Arias MC, Garcia-Estevez $\mathrm{JM}$, et al. Eimeria species from the European pond turtle, Emys orbicularis (Reptilia: Testudines), in Galicia (NW Spain) with description of two new species. J Parasitol 2006; 92: 69-72. [CrossRef]

2. McAllister CT, Barger MA, Stuart JN. Neoechinorhynchus emyditoides Fisher, 1960 (Acanthocephala: Neoechinorhynchidae) from the Mexican plateau slider, Trachemys gaigeae (Testudines: Emydidae) in New Mexico, USA. Comp Parasitol 2008; 75: 135-7. [CrossRef]

3. Zelmer DA, Platt TR. Structure and similarity of helminth communities of six species of Australian turtles. J Parasitol 2008; 94: 781-7. [CrossRef]

4. Telford SR. Hemoparasites of the Reptilia. New York: CRC Press; 2009.

5. Campbell TW, Ellis CK. Avian and Exotic Animal Hematology and Cytology. lowa: Blackwell Publishing; 2007.

6. Danilewsky B. Die Hamatozoen der kaltbluter. Arch Mikrosk Anat 1885; 24: 588-98. [CrossRef]

7. ReichnowE. Haemogregarinastepanowi Die Entwicklungsgeschichte einer Hemogregarine. Arch Protistenk 1910; 20: 251-350.

8. Simond PL. Contribution al etude des hematozoires endoglobulaires des reptiles. Annls Inst Pasteur Paris 1901; 15: 319.

9. Wang CC, Hopkins SH. Haemogregarina and Haemoproteus (Protozoa, Sporozoa) in blood of Texas freshwater turtles. J Parasitol 1965; 51: 682-3. [CrossRef]

10. Marquard WC. Haemogregarines and Haemoproteus in some reptiles in Southern Illinois. J Parasitol 1966; 52: 823-4. [CrossRef]

11. Strohlein DA, Christensen BM. Haemogregarina sp (Apicomplexa, Sporozoea) in aquatic turtles from Murphys Pond, Kentucky. Trans Am Microscopical Soc 1984; 103: 98-101. [CrossRef]

12. McAuliffe JR. An hypothesis explaining variations of hemogregarine parasitemia in different aquatic turtle species. J Parasitol 1977; 63: 580-1. [CrossRef]

13. Acholonu AD. Haemogregarina pseudemydis n. sp. (Apicomplexa: Haemogregarinidae) and Pirhemocyton chelonarum n. sp. in turtles from Louisiana. J Protozool 1974; 21: 659-64.

14. Edney JM. Haemogregarina stepanowi Danilewsky (1885) in middle Tennessee turtles. J Tenn Acad Sci 1949; 24: 220-3.

15. Siddall ME, Desser SS. Prevalence and intensity of Haemogregarina balli (Apicomplexa, Adeleina, Haemogregarinidae) in three turtle species from ontario, with observations on intraerythrocytic development. Canadian J Zool 1992; 70: 123-8. [CrossRef]

16. Caudell JN, Whittier J, Conover MR. The effects of haemogregarine- like parasites on brown tree snakes (Boiga irregularis) and slatey-grey snakes (Stegonotus cucullatus) in Queensland, Australia. Int Biodet Biodegrad 2002; 49: 113-9. [CrossRef]

17. O'Dwyer LH, Moco TC, da Silva RJ. Description of the gamonts of a small species of Hepatozoon sp. (Apicomplexa, Hepatozoidae) found in Crotalus durissus terrificus (Serpentes, Viperidae). Parasitol Res 2004; 92: 110-2. [CrossRef]

18. Sheldon BC, Verhulst S. Ecological inmunology: costly parasite defences and trade-offs in evolutionary ecology. Trends Ecol Evol 1996; 11: 317-21. [CrossRef]

19. Smith TG, Desser SS, Martin DS. The development of Hepatozoon sipedon n. sp. (Apicomplexa: Adeleina: Hepatozoidae) in its natural host, the Northern water snake (Nerodiasipedon sipedon), the culicine vectors, Culex pipiens and Culex territans, and an intermediate host, Northern leopard frog (Rana pipiens). Parasitol Res 1994; 80: 559-68. [CrossRef] 
20. Caudell JN, Whittier J, Conover MR. The effects of haemogregarine- like parasites on brown tree snakes (Boiga irregularis) and slatey-grey snakes (Stegonotus cucullatus) in Queensland, Australia. Int Biodet Biodegrad 2002; 49: 113-9. [CrossRef]

21. Lainson R, de Souza MC, Franco CM. Haematozoan parasites of the lizard Ameiva ameiva (Teiidae) from Amazonian Brazil: a preliminary note. Mem Inst Oswaldo Cruz 2003; 98: 1067-70. [CrossRef]

22. Wintrobe MM. Clinical haematology. Philadelphia: Lea and Feiberger; 1991.

23. Oppliger A, Celerier ML, Clobert J. Physiological and behaviour changes in common lizards parasited by haemogregarines. Parasitol 1996; 113: 433-8. [CrossRef]

24. Veiga JP, Salvador A, Merino S, Puerta M. Reproductive effort affects immune response and parasite infection in a lizard: a phenotypic manipulation using testosterone. Oikos 1998; 82: 313-8. [CrossRef]

25. Paperna I. Developmental cycle of chelonian hemogregarines in leeches with extra-intestinal multiple sporozoite oocysts and a note on the blood stages in the chelonian hosts. Dis Aquatic Organisms 1989; 7: 149-53. [CrossRef]

26. Siddall ME, Desser SS. Transmission of Haemogregarina balli from painted turtles to snapping turtles through the leech Placobdella ornata. J Parasitol 2001; 87: 1217-8. [CrossRef]

27. Readel AM, Phillips CA, Wetzel MJ. Leech parasitism in a turtle assemblage: Effects of host and environmental characteristics. Copeia 2008; 1: 227-33. [CrossRef]

28. Knotkova Z, Mazanek S, Hovorka M, Sloboda M, Knotek Z. Haematology and plasma chemistry of Borne an river turtles suffering from shell necrosis and haemogregarine parasites. Vet Medicina 2005; 50: 421-6.

29. Ryan TJ, Lambert A. Prevalence and colonization of Placobdella on two species of freshwater turtles (Graptemys geographica and Sternotherus odoratus). J Herpetol 2005; 39: 284-7. [CrossRef]
30. Strohlein DA, Christensen BM. Haemogregarina sp (Apicomplexa, Sporozoea) in aquatic turtles from Murphys Pond, Kentucky. Trans Am Microscopical Soc 1984; 103: 98-101. [CrossRef]

31. McCoy JC, Failey EL, Price SJ, Dorcas ME. An assessment of leech parasitism on semi-aquatic turtles in the Western Piedmont of North Carolina. Southeast Nat 2007; 6: 191-202. [CrossRef]

32. Paperna I, Kremer-Mecabell T, Finkelman S. Hepatozoon kisrae $n$. sp. infecting the lizard Agama stellio is transmitted by the tick Hyalomma cf. aegyptium. Parasite 2002; 9: 17-27.

33. Smith TG, Desser SS. Phylogenetic analysis of the genus Hepatozoon Miller, 1908 (Apicomplexa: Adeleorina). Syst Parasitol 1997; 36: 213-21.. [CrossRef]

34. Jakes KA, O'Donoghue PJ, Cameron SL. Phylogenetic relationships of Hepatozoon (Haemogregarina) boigae, Hepatozoon sp., Haemogregarina clelandi and Haemoproteus chelodina from Australian reptiles to other Apicomplexa based on cladistic analyses of ultrastructural and life-cycle characters. Parasitol 2003; 126: 555-9.

35. Smith TG. The genus Hepatozoon (Apicomplexa: Adeleina). J Parasitol 1996; 82: 565-85. [CrossRef]

36. Paperna I, Lainson R. Hepatozoon cf. terzii (Sambon \& Seligman, 1907) infection in the snakes Boaconstrictor constrictor from North Brazil: Transmission to the mosquito Culex quinquefasciatus and the lizards Tropidurus torquatus. Parasite 2004; 11: 175-81.

37. Jakes KA. O'Donoghue P, Munro M, Adlard R. Hemoprotozoa of freshwater turtles in Queensland. J Wildlife Dis 2001; 37: 12-9.

38. Mihalca AD, Achelaripei D, Popescu P. Haemoparasites to the genus Haemogregarina in a populaion of European pond turtles (Emys orbicularis) from Dragasani, Valcea country, Romania. Rev Sci Parasitologica 2002; 3: 22-7. 